\title{
Ventilation-Mediated Injury After Preterm Delivery of Ureaplasma parvum Colonized Fetal Lambs
}

\author{
GRAEME R. POLGLASE, NOAH H. HILLMAN, J. JANE PILLOW, ILIAS NITSOS, JOHN P. NEWNHAM, CHRISTINE L. KNOX, \\ SUHAS G. KALLAPUR, AND ALAN H. JOBE
}

\begin{abstract}
School of Women's and Infants' Health [G.R.P., J.J.P., I.N., J.P.N.], The University of Western Australia, Subiaco, Western Australia 6009, Australia; Division of Pulmonary Biology [N.H.H., S.G.K., A.H.J.], University of Cincinnati School of Medicine, Cincinnati, Ohio 45229; Institute of Health and Biomedical Innovation [C.L.K.], Queensland University of Technology, Brisbane, Queensland 4001, Australia
\end{abstract}

\begin{abstract}
Ureaplasma species are the microorganisms most frequently isolated from women with preterm birth and are associated with an increased risk of bronchopulmonary dysplasia. Initiation of ventilation with high tidal volumes $\left(V_{\mathrm{T}}\right)$ causes lung injury and inflammation. We investigated whether antenatal colonization with Ureaplasma parvum serovar 3 (UP) would alter the inflammatory response to mechanical ventilation of preterm lambs. Merino ewes were given intraamniotic injections of UP at 55-d gestation, and the lambs were surgically delivered at $128 \pm 1 \mathrm{~d}$ gestation and assigned to three groups: 1) gentle ventilation $(\mathrm{GV}), 2)$ high $V_{\mathrm{T}}$ ventilation, or 3) unventilated control. Lambs delivered from noncolonized ewes were assigned to parallel groups. GV lambs received surfactant before ventilation with a $V_{\mathrm{T}}$ of $7 \mathrm{~mL} / \mathrm{kg}$, positive end expiratory pressure (PEEP) $5 \mathrm{~cm} \mathrm{H}_{2} \mathrm{O}$. High $V_{\mathrm{T}}$ lambs received no PEEP and escalating $V_{\mathrm{T}}$ to $15 \mathrm{~mL} / \mathrm{kg}$ by $15 \mathrm{~min}$. At $15 \mathrm{~min}$, surfactant was given, $V_{\mathrm{T}}$ was reduced to $7 \mathrm{~mL} / \mathrm{kg}$, and PEEP was increased to $5 \mathrm{~cm}$ $\mathrm{H}_{2} \mathrm{O}$. Monocytes in bronchoalveolar lavage were increased by UP, but colonization did not affect lung function. High $V_{\mathrm{T}}$ ventilation increased Egr-1 signaling, proinflammatory cytokine expression, and injury scores compared with GV. Antenatal colonization with UP did not change lung function or modulate the lung injury and inflammation caused by high $V_{\mathrm{T}}$ ventilation. (Pediatr Res 67: 630-635, 2010)
\end{abstract}

$\mathrm{H}^{\mathrm{is}}$ igh tidal volume $\left(V_{\mathrm{T}}\right)$ resulting in overdistension of the lung causes ventilator-induced lung injury (VILI) (1). The preterm lung is particularly susceptible to VILI as it is structurally immature, surfactant deficient, and has lower potential gas volumes compared with the lungs of term infants or adult lungs (2). Exposure to inflammation in utero is a frequent occurrence in preterm infants (3), is causatively related to preterm birth (4), and may increase the risk and the severity of bronchopulmonary dysplasia (BPD) $(5,6)$. Ureaplasma species are the most frequently isolated bacteria from amniotic fluid of women whom have delivered before 32-wk gestation, and airway colonization with ureaplasmas in preterm infants is associated with an increased risk of $\operatorname{BPD}(7,8)$.

Received October 26, 2009; accepted February 11, 2010.

Correspondence: Graeme Polglase, Ph.D., School of Women's and Infants' Health, The University of Western Australia, M094, 35 Stirling Highway, Crawley, Western Australia, Australia; e-mail: graeme.polglase@uwa.edu.au

Supported by NICHD 12714 and the Women and Infants Research Foundation, NHMRC and NHFA Fellowship (G.R.P.), Sylvia and Charles Viertel Senior Medical Research Fellowship (J.J.P.) and NHLBI K08HL097085 (N.H.H.). Grant support, CPAP circuits, humidifiers, and radiant warmer beds were provided by Fisher \& Paykel Healthcare $^{\text {TM }}$ (NZ). Chiesi Faraceuticals, S.p.A, Parma, Italy provided a gift of surfactant.
Fetal sheep can be chronically colonized with Ureaplasma parvum (UP) serovars 3 or 6 from early gestation $(9,10)$. Ultrasound guided intraamniotic injections of live UP can be given as early as $50 \mathrm{~d}$ gestation and the fetuses remain colonized at term. UP is more commonly associated with preterm birth than $U$. urealyticum, and serovar 3 is the most common ureaplasma serovar isolated from women, men, pregnant women, and infertile couples (11-13). This ureaplasma colonization model in fetal sheep replicates the chronic and indolent human fetal exposure to ureaplasmas that can result in preterm birth (14) or may be tolerated by the pregnancy without overt pathology (15). As in the human, fetal sheep colonized with ureaplasmas can have induced lung maturation and indicators of chronic lung inflammation (16). Acute ureaplasma infection of fetal baboons seemed to increase lung injury with chronic ventilation at birth (17). However, the effects of mechanical ventilation associated with the initiation of ventilation on fetal lungs with chronic ureaplasma infection are unknown. Our previous studies with acute exposures to lipopolysaccharide (LPS) showed an amplification of inflammation with ventilation (18). However, chronic fetal proinflammatory exposures may result in a tolerance phenomenon with suppressed inflammation (19). We hypothesize that chronic fetal UP colonization would augment inflammation and lung injury after preterm delivery and an initial high $V_{\mathrm{T}}$ ventilation designed to injure the preterm lung (20).

\section{METHODS}

The investigations were approved by the Animal Ethics Committees of the University of Western Australia and Cincinnati Children's Hospital Medical Center. Low passage UP serovar 3 was cultured, concentrated, and stored at $-80^{\circ} \mathrm{C}$ as described previously (16). These microorganisms were thawed and diluted in sterile cold phosphate buffered saline to $2 \times 10^{4}$ colony forming units (CFU) in a $2 \mathrm{~mL}$ injection volume. Singleton Merino ewes were given intraamniotic injections at 55-d gestation (term is $150 \mathrm{~d}$ ) using ultrasound guidance (16). Comparison sheep were not given the intraamniotic injections but were bred, housed, and delivered concurrently with the UP injected animals.

Abbreviations: BAL, Bronchoalveolar lavage; BPD, Bronchopulmonary dysplasia; Egr-1, Early growth response protein 1; GV, Gentle ventilation; OI, Oxygenation Index; PEEP, Positive end expiratory pressure; PIP, Peak inspiratory pressure; UVC, Unventilated controls; VEI, Ventilator Efficiency Index; VILI, Ventilator-induced lung injury; $\boldsymbol{V}_{\mathrm{T}}$, Tidal volume 
Fetuses were randomized to study groups before delivery $(n=6-8$ animals/group). Ewes at $128 \pm 1 \mathrm{~d}$ gestation were anesthetized with an i.v. injection of Ketamine $(10 \mathrm{mg} / \mathrm{kg}$; Parnell Labs, NSW, Australia) and Medetomidine $(0.1 \mathrm{mg} / \mathrm{kg} 2 \mathrm{~min}$; Domitor, Pfizer Animal Health, NSW, Australia) and then received spinal anesthesia (2\% Lidocaine; $60 \mathrm{mg}$ ) before delivery of fetuses. After delivery of the head, each lamb received local anesthesia with Lidocaine before tracheostomy placement of a $4.5 \mathrm{~mm}$ internal diameter endotracheal tube, inserted to a depth of $8 \mathrm{~cm}$, and tied securely to exclude leak. Cord blood samples were collected from each animal. After delivery, each lamb was weighed and positive pressure ventilation begun (Babylog 8000+, Dräger, Lübeck, Germany) according to group assignment to either a gentle ventilation (GV) strategy or 15 min high $V_{\mathrm{T}}$ ventilation to injure the lungs. Lambs from ureaplasma (UP) exposed and control groups randomized to the GV strategy received surfactant (Poractant alpha, Chiesi Farmaceuticials S.p.A. Parma, Italy) before initiation of ventilation with a peak inspiratory pressure (PIP) of $35 \mathrm{~cm} \mathrm{H}_{2} \mathrm{O}$, a positive end expiratory pressure (PEEP) of $5 \mathrm{~cm} \mathrm{H}_{2} \mathrm{O}$, and a rate of 40 breaths/min using heated and humidified $40 \%$ oxygen with an inspiratory time of $0.6 \mathrm{~s}$. PIP was adjusted to a target $V_{\mathrm{T}}$ of $7 \mathrm{~mL} / \mathrm{kg}$ by $15 \mathrm{~min}$ and adjusted throughout the subsequent $2 \mathrm{~h} 45 \mathrm{~min}$ of ventilation to target a $\mathrm{PaCO}_{2}$ of $50-60 \mathrm{~mm} \mathrm{Hg}$, with a PIP upper limit of $40 \mathrm{~cm} \mathrm{H}_{2} \mathrm{O}$, and $V_{\mathrm{T}}$ of $10 \mathrm{~mL} / \mathrm{kg}$. Fraction of inspired oxygen was adjusted to maintain an arterial saturation between 88 and $95 \%$. Lambs randomized to the high $V_{\mathrm{T}}$ ventilation strategy had $V_{\mathrm{T}}$ targets of 8-10 $\mathrm{mL} / \mathrm{kg}$ at $5 \mathrm{~min}, 12 \mathrm{~mL} / \mathrm{kg}$ at $10 \mathrm{~min}$, and $15 \mathrm{~mL} / \mathrm{kg}$ by $15 \mathrm{~min}$, followed by surfactant treatment and ventilation similar to the noninjurious lambs for the remaining 2 h 45 min study period. Unventilated controls (UVC) and unventilated UP (UP UVC) fetuses were euthanized before delivery and were sampled immediately.

The ventilated lambs had umbilical arterial and venous catheters placed soon after birth, and were anesthetized for ventilation with continuous umbilical venous infusions of Remifentanil $(0.05 \mu \mathrm{g} / \mathrm{kg} / \mathrm{min}$; Ultiva, Glaxo Smith Kline Ltd., Victoria, Australia) and Propofol (0.1 mg/kg/min: Repose, Norbrook Laboratories Ltd., Victoria, Australia). Blood-gas values and ventilation variables were recorded at $30 \mathrm{~min}$ intervals throughout the ventilation. Ventilation Efficiency Index (VEI) was calculated as 3800/[(PIP-PEEP) $\times$ ventilator rate $\left.\times \mathrm{PaCO}_{2}\right]$ (21). Oxygenation Index calculated as fraction of inspired oxygen $\times$ mean airway pressure $\times 100 / \mathrm{PaO}_{2}$. The animals were killed with i.v. pentobarbital $(100 \mathrm{mg} / \mathrm{kg}) 3 \mathrm{~h}$ after delivery.

Lung processing and bronchoalveolar lavage fluid analysis. At autopsy, a deflation pressure-volume curve was measured after gas inflation to $40 \mathrm{~cm}$ $\mathrm{H}_{2} \mathrm{O}$ pressure (22). Bronchoalveolar lavage fluid (BAL) of the left lung was used to determine total protein content (23) and differential cell counts after cytospins. Tissue from the left lung was snap frozen for RNA isolation, and $10 \mu \mathrm{g}$ of total RNA was used for IL- $1 \beta$ and IL-6 RNAse protection assays $(24,25)$. The right upper lobe was inflation fixed with $10 \%$ formalin $(26)$, and this tissue was used for injury scores. Ten random high power fields were scored on a $0-2$ scale for alveolar wall thickness, hemorrhage, inflammation, and epithelial sloughing (total 8 points) (27).

Immunohistochemistry. Immunostaining protocols used paraffin sections $(5 \mu \mathrm{m})$ of formalin fixed tissues that were pretreated with $3 \%$ hydrogen peroxide to inactivate endogenous peroxidases $(28,29)$. The sections were incubated with anti-human Early response protein-1 (Egr-1) 1:250 dilution (Santa Cruz, USA), iN0S anti-mouse 1:250 (BD Transduction, USA), or Mouse anti-ovine IL-8 1:250 (Chemicon, USA) in 4\% normal goat serum overnight, followed by biotin labeled secondary antibody. Immunostaining was visualized by Vectastain ABC Peroxidase Elite kit to detect the antigen:antibody complexes (Vector Laboratories Inc, USA). The antigen detection was enhanced with nickel-DAB, followed by Tris-cobalt and the nuclei counterstained with eosin (Egr-1) or nuclear fast red (IL-8, iNOS) (29). Results are expressed as the number of EGR-1 positive cells per high powered field. Weigert's staining (Poly Scientific, USA) was performed on paraffin blocks to evaluate elastin.
Data analysis and statistics. Results are shown as mean (SEM). Statistics were analyzed using SigmaStat 3.5 (Systat Software, Inc., San Jose, CA). For normally distributed data, a two-way or three-way analysis of variance with the Holm-Sidak multiple comparison procedure was used for comparisons between ventilation groups using time, treatment, and ventilation strategy as variables. Significance was accepted as $p<0.05$.

\section{RESULTS}

The animals randomized to each group had similar body weights and cord blood gas values. UP colonization was confirmed by culturing the tissues from all lambs exposed to ureaplasmas intraamniotically. No ureaplasmas were detected in the tissues of the control lambs. The UP titer ranged from $8.3 \times 10^{3}$ to $1.5 \times 10^{7} \mathrm{CFU} / \mathrm{mL}$ in the amniotic fluid and $7.3 \times 10^{3}$ to $1.3 \times 10^{5} \mathrm{CFU} / \mathrm{g}$ of chorioamnion. Because of the sampling technique, titers were not taken from lung tissue or BAL. Many of the ureaplasma exposed animals had edematous cords and membranes noted at delivery. Unventilated fetal controls $(n=8)$ had $0.4 \pm 0.5 \times 10^{5}$ monocytes $/ \mathrm{kg} \mathrm{BW}$ and the UP UVC $(n=6)$ had $80 \pm 10 \times 10^{5}$ monocytes $/ \mathrm{kg}$ BW in BAL $(p<0.05)$. There were no differences in neutrophil recruitment to BAL, injury scoring, or Egr-1 protein signal between UVC groups.

Ventilation and oxygenation. All ventilated groups achieved their assigned $V_{\mathrm{T}}$ over the first $15 \mathrm{~min}$ (Table 1) with both GV groups achieving approximately $7 \mathrm{~mL} / \mathrm{kg}$ and high $V_{\mathrm{T}}$ groups receiving greater than $13 \mathrm{~mL} / \mathrm{kg} . V_{\mathrm{T}}$ increased to higher values at 5 and $10 \mathrm{~min}$ in the high $V_{\mathrm{T}}$ lambs. $V_{\mathrm{T}}$ at $3 \mathrm{~h}$ was not different between groups $(p=0.76)$. PIP was significantly higher in high $V_{\mathrm{T}}$ lambs compared with GV lambs at $15 \min (p<0.05)$ and the higher pressures persisted to $3 \mathrm{~h}$ $\left(p=0.03\right.$; Table 1). Although $V_{\mathrm{T}}$ was similar for the four ventilated groups at $3 \mathrm{~h}$, the PIP required to obtain these values were increased for the unexposed and UP high $V_{\mathrm{T}}$ groups. Exposure to ureaplasmas did not change the initial $V_{\mathrm{T}}$ or PIP values or $3 \mathrm{~h}$ values relative to the unexposed groups.

$\mathrm{PaCO}_{2}$ progressively increased for the high $V_{\mathrm{T}}$ groups over the ventilation period after 120 min compared with GV lambs $(p<0.05$; Fig. 1A). Oxygenation index was higher (worse) in high $V_{\mathrm{T}}$ lambs compared with GV lambs throughout the $3 \mathrm{~h}$ of ventilation ( $p=0.05$; Fig. $1 B$ ). No effect of antenatal exposure to ureaplasma was identified. $\mathrm{PaO}_{2}$ was higher in high $V_{\mathrm{T}}$ lambs compared with GV lambs at 15 and 30 min but was not different between any groups during the remaining ventilation period $\left(\mathrm{PaO}_{2}\right.$ range $35-55 \mathrm{~mm} \mathrm{Hg}$ after $\left.30 \mathrm{~min}\right)$. VEI was significantly higher in $\mathrm{GV}$ lambs compared with high $V_{\mathrm{T}}$ lambs irrespective of antenatal treatment $(p<0.05$; Fig. $1 C)$.

Table 1. Ventilated animals

\begin{tabular}{|c|c|c|c|c|c|c|c|c|c|}
\hline \multirow[b]{2}{*}{ Group } & \multirow[b]{2}{*}{$n$} & \multirow[b]{2}{*}{ BW } & \multirow[b]{2}{*}{$\mathrm{V} 40 / \mathrm{kg}$} & \multicolumn{4}{|c|}{$V_{\mathrm{T}}(\mathrm{mL} / \mathrm{kg})$} & \multicolumn{2}{|c|}{$\mathrm{PIP}\left(\mathrm{cm} \mathrm{H}_{2} \mathrm{O}\right)$} \\
\hline & & & & $5 \mathrm{~min}$ & $10 \mathrm{~min}$ & $15 \mathrm{~min}$ & $3 \mathrm{~h}$ & $15 \mathrm{~min}$ & $3 \mathrm{~h}$ \\
\hline GV & 8 & $2.7 \pm 0.1$ & $48 \pm 25$ & $4.7 \pm 1.9$ & $7.9 \pm 0.2$ & $7.5 \pm 0.1$ & $6.9 \pm 0.5$ & $31.9 \pm 1.5$ & $24.5 \pm 1.4$ \\
\hline High $V_{\mathrm{T}}$ & 7 & $3.0 \pm 0.1$ & $29 \pm 15$ & $7.3 \pm 1.0^{*}$ & $10.3 \pm 1.3^{*}$ & $13.2 \pm 1.8^{*}$ & $7.7 \pm 0.7$ & $43.8 \pm 3.4^{*}$ & $33.0 \pm 4.0^{*}$ \\
\hline $\mathrm{GV}+\mathrm{UP}$ & 6 & $3.2 \pm 0.3$ & $53 \pm 7$ & $4.7 \pm 0.4$ & $6.7 \pm 1.6$ & $6.8 \pm 1.2$ & $8.2 \pm 1.2$ & $31.2 \pm 2.2$ & $25.2 \pm 0.7$ \\
\hline High $V_{\mathrm{T}}+\mathrm{UP}$ & 5 & $3.3 \pm 0.2$ & $36 \pm 13^{*}$ & $7.5 \pm 0.1^{*}$ & $10.1 \pm 0.2^{*}$ & $14.2 \pm 1.9^{*}$ & $7.4 \pm 0.5$ & $45.9 \pm 3.0^{*}$ & $28.5 \pm 4.8^{*}$ \\
\hline
\end{tabular}

Data are presented as mean $\pm \mathrm{SD}$.

$* p<0.05$ injury $v s$ no injury.

$\mathrm{GV}$, gentle ventilation; High $V_{\mathrm{T}}$, volutrauma in first $15 \mathrm{~min}$; UP, Ureaplasma parvum; $V_{\mathrm{T}}$, tidal volume; PIP, peak inspiratory pressure; BW, birth weight; V40, volume at $40 \mathrm{~cm} \mathrm{H}_{2} \mathrm{O}$. 

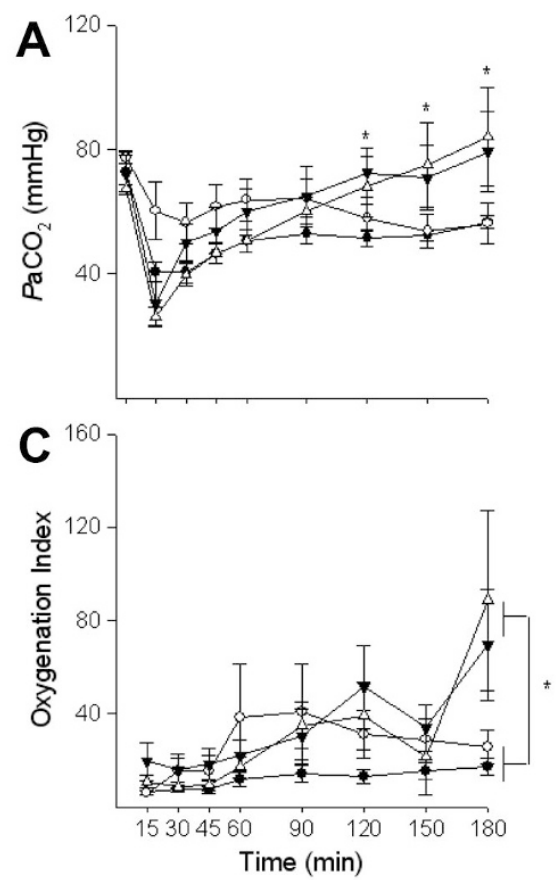

B
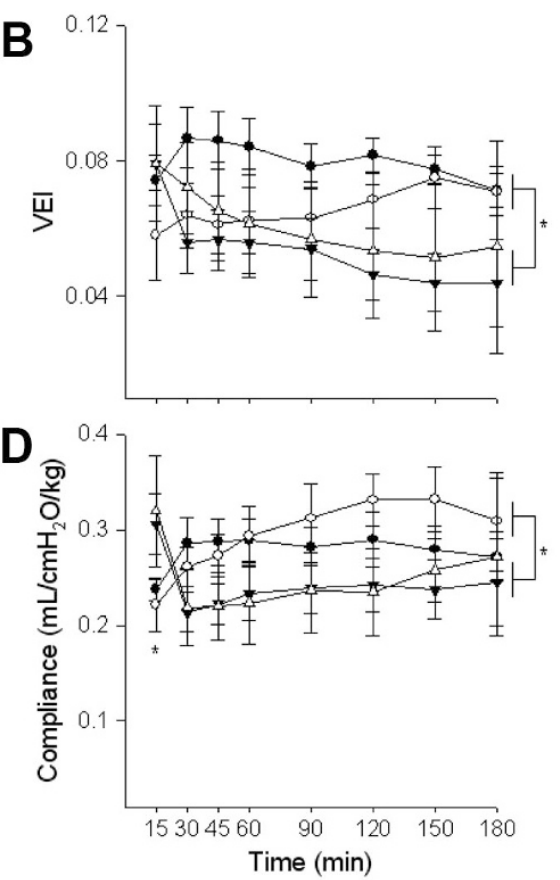

Figure 1. $\mathrm{PaCO}_{2}(A)$, Oxygenation Index (OI; $B)$, ventilation efficiency index (VEI; $C$ ), and compliance $(D)$ during ventilation of lambs exposed antenatally to UP (open symbols) or saline (closed symbols). The high $V_{\mathrm{T}}$ ventilation strategy in each group is indicated by triangles. $\mathrm{PaCO}_{2}$ and OI were higher, whereas VEI and compliance were lower in injury lambs compared with controls, irrespective of antenatal treatment. $* p<0.05$.

Table 2. Markers of lung inflammation and injury

\begin{tabular}{lccccccc}
\hline \multicolumn{1}{c}{ Group } & $\begin{array}{c}\text { BAL protein } \\
(\mathrm{mg} / \mathrm{kg})\end{array}$ & $\begin{array}{c}\text { Injury } \\
\text { score }\end{array}$ & $\begin{array}{c}\text { EGR-1 } \\
(\text { cells/hpf })\end{array}$ & $\begin{array}{c}\text { BAL neutrophils } \\
\left(\times 10^{6} \mathrm{~kg} / \mathrm{Bwt}\right)\end{array}$ & $\begin{array}{c}\text { BAL monocytes } \\
\left(\times 10^{5} \mathrm{~kg} / \mathrm{Bwt}\right)\end{array}$ & $\begin{array}{c}\text { IL-1 } \beta \text { mRNA } \\
(\text { fold increase })^{*}\end{array}$ & $\begin{array}{c}\text { IL-6 mRNA } \\
(\text { fold increase })^{*}\end{array}$ \\
\hline $\mathrm{GV}$ & $59 \pm 11$ & $1.8 \pm 0.5$ & $64 \pm 21$ & $14.0 \pm 5.7$ & $7.0 \pm 2.0$ & $1.0 \pm 0.2$ \\
$\mathrm{High} V_{\mathrm{T}}$ & $107 \pm 11 \dagger$ & $5.0 \pm 0.5 \dagger$ & $148 \pm 31 \dagger$ & $27.6 \pm 7.6 \dagger$ & $9.8 \pm 4.4$ & $3.1 \pm 2.4$ & $2.0 \pm 1.2$ \\
$\mathrm{GV}+\mathrm{UP}$ & $50 \pm 5$ & $1.4 \pm 0.4$ & $26 \pm 98.5$ & $17.7 \pm 5.3$ & $48.4 \pm 1.7 \ddagger$ & $1.6 \pm 1.6$ & $0.7 \pm 0.4$ \\
High $V_{\mathrm{T}}+\mathrm{UP}$ & $99 \pm 8 \dagger$ & $3.5 \pm 0.9 \dagger$ & $84 \pm 10 \dagger$ & $24.0 \pm 4.3 \dagger$ & $40.8 \pm 2.0 \ddagger$ & $2.8 \pm 1.0$ & $4.4 \pm 5.1$ \\
\hline
\end{tabular}

* Compared with GV group, normalized to value of 1 .

$\dagger p<0.05$ injury $v s$ no injury.

$\ddagger p<0.05$ Ureaplasma vs saline.

$\mathrm{GV}$, gentle ventilation; High $V_{\mathrm{T}}$, volutrauma in first $15 \mathrm{~min}$; UP, Ureaplasma parvum; BAL, bronchoalveolar lavage fluid.

VEI was maintained throughout the ventilation strategy in GV lambs, but decreased over time in high $V_{\mathrm{T}}$ lambs $(p<0.05)$. Compliance was higher in high $V_{\mathrm{T}}$ lambs at 15 min but was lower than GV lamb throughout the remaining ventilation strategy ( $p<0.05$; Fig. $1 D$ ); no effect of antenatal ureaplasma exposure was present. The lung gas volume at $40 \mathrm{~cm} \mathrm{H}_{2} \mathrm{O}$ from the pressure-volume curve demonstrated decreased static compliance in UP high $V_{\mathrm{T}}$ lambs compared with GV, with similar trend in unexposed lambs (Table 1). The lung gas volume at $40 \mathrm{~cm} \mathrm{H}_{2} \mathrm{O}$ was not different between UVC groups.

Lung inflammation and injury. Total protein in the lung BALF was significantly higher in high $V_{\mathrm{T}}$ lambs compared with GV lambs irrespective of UP exposure (Table 2). Injury scores were also higher in high $V_{\mathrm{T}}$ lambs compared with GV lambs (Table 2); no effect of ureaplasmas was observed. Elastin staining did not differ significantly between the groups. EGR-1 staining was higher in high $V_{\mathrm{T}}$ lambs compared with GV lambs (Fig. 2). iNOS staining was seen in blood vessels of all animals, but there were no other positive cells throughout the lung parenchyma or airspaces (data not shown). IL-8 immunostaining was negative for all intervention groups, irrespective of prior ureaplasma exposure (data not shown).

Neutrophils in BAL/kg bodyweight were significantly higher in high $V_{\mathrm{T}}$ lambs compared with GV lambs (Table 2) but were not altered by UP exposure. Monocytes $/ \mathrm{kg}$ were significantly higher in lambs exposed to UP compared with controls (Table 2 ), with no effect of ventilation strategy. IL- $1 \beta$ and IL-6 mRNA were similar between groups with trends toward increased values with high $V_{\mathrm{T}}$ ventilation.

\section{DISCUSSION}

Inflammation is a cause of preterm birth and may have a role in the development of BPD (30). We investigated the role of chronic UP serovar 3 colonization on the inflammatory response to VILI — one of the leading associations with BPD (31). We showed that ureaplasma colonization from 55-d gestation did not alter the inflammatory response to normal or injurious ventilation after preterm delivery at $124 \mathrm{~d}$.

We previously showed that UP colonization at $80 \mathrm{~d}$ increased saturated phosphatidylcholine pool size at $125 \mathrm{~d}$ and $145 \mathrm{~d}$ indicating a maturation response of the lung (16). Ventilated lambs in this study were given surfactant, so measurements of the amount of surfactant were not conducted at post mortem. In GV groups, surfactant was intentionally given to negate possible differences in the endogenous surfactant. Lambs colonized at 80-d gestation had increased IL-8 positive cells in the lung and increased inflammatory cell 


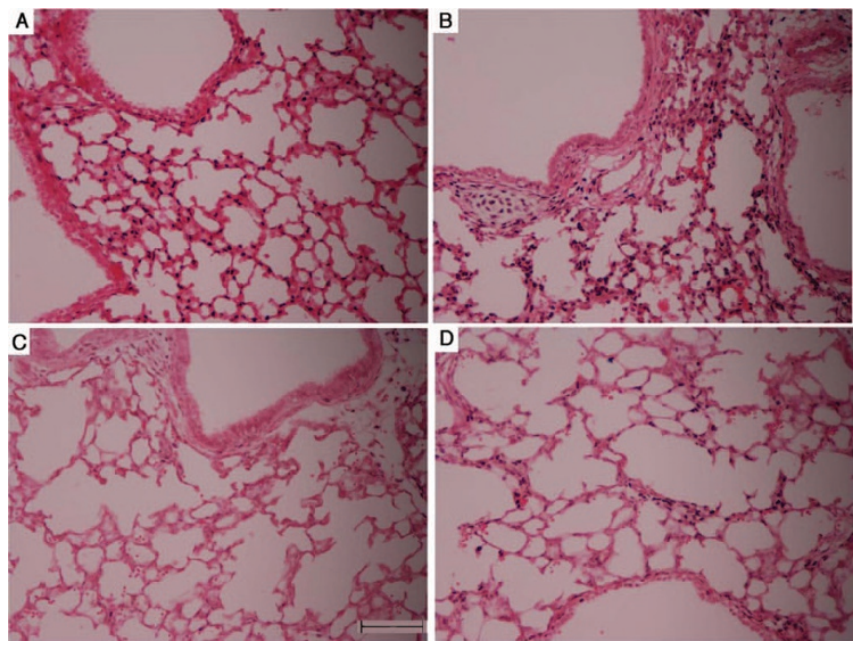

Figure 2. Egr-1 immunohistochemistry. Gentle ventilation $(A)$ demonstrates increased signal surrounding smaller airways. High $V_{\mathrm{T}}$ ventilation group $(B)$ has increased staining through the lung parenchyma. Antenatal UP exposure demonstrates less staining with both gentle ventilation $(C)$ and high $V_{\mathrm{T}}$ ventilation $(D)$ compared with saline groups $(\mathrm{A}$ and $\mathrm{B}) . \times 40$ magnification, Scale bar $=25 \mu \mathrm{m}$.

influx in the chorioamnion (16). Lambs exposed to ureaplasmas at 55-d gestation had increased BAL inflammatory cell counts (9). Although we did not find growth restriction with these lambs, increased inflammatory cells, especially monocytes, were seen in the UP UVC animals compared with unventilated, nonexposed animals. We did not find inflammatory cell activation as indicated by the lack of iNOS or IL-8 expression. Although the inoculation dose differed between the studies $\left(2 \times 10^{7} \mathrm{CFU}\right.$ injected in previous experiment and $2 \times 10^{4} \mathrm{CFU}$ in this report), we documented amniotic fluid colonization with UP (average $\mathrm{CFU} / \mathrm{mL} 1.7 \times 10^{6}$ ) in this study and lambs had evidence of edematous umbilical cords and membranes. Although the current model did not cause the inflammatory changes seen previously, it mimics the human model of chronic ureaplasma colonization with preterm labor, where approximately $44 \%$ women with preterm labor had $>10^{4} \mathrm{CFU}$ of $U$. urealyticum (32).

Our previous models of chronic amniotic inflammation, using continuous infusions of LPS in preterm lambs, did not cause sustained lung remodeling and inflammatory responses (33). Similarly, chronic colonization with UP serovar 3 also did not have a significant effect on lung or vascular morphometry at delivery (9). Although lung morphometry was not performed on these animals, we did not observe changes on hematoxylin and eosin stains of unventilated ureaplasma infected controls. Human infants with ureaplasma pneumonitis develop increased pulmonary myofibroblast activation and disordered elastin formation (34). Baboons exposed to antenatal ureaplasma and then ventilated for $14 \mathrm{~d}$ have increased $\alpha$-smooth muscle actin and fibrosis (35). In our model, we did not find differences in the elastin staining between ureaplasma exposed and control lambs.

The lack of an effect of ureaplasma colonization on ventilation variables and lung injury was contrary to our hypothesis. Preterm baboons exposed to antenatal UP serovar $1(1 \times$ $10^{7} \mathrm{CFU}$ ) injected $48-72 \mathrm{~h}$ before preterm delivery and ventilated for $14 \mathrm{~d}$ had significantly worse respiratory function and increased proinflammatory cytokines relative to uninfected controls (17). Infected baboons demonstrated profibrotic and proinflammatory changes in the lungs (35). Half of these baboons were able to clear the ureaplasmas from the tracheal aspirates during the ventilation period (17). The major differences between our study and that of Yoder et al. are the longer exposure time in utero to ureaplasmas and the shorter postnatal ventilation time. Although the profile of the acute pulmonary inflammatory response to ureaplasmas is not known, it is likely that the short exposure time to ureaplasmas in utero in the baboons was not sufficient to cause lung maturation (17) or not long enough for the acute inflammatory response to be resolved (33). Indeed, we have previously shown in LPS exposed lambs that chorioamnionitis precedes lung maturation (24). Thus, it is likely that these baboons were delivered during the acute inflammatory response of the lung to ureaplasmas, which would result in an exacerbated inflammatory response to ventilation and subsequent worse respiratory function. Evidence for an acute inflammatory response to ureaplasmas is shown in Rhesus Macaques exposed to intraamniotic UP serovar 1 . Within the first $5 \mathrm{~d}$, large collections of neutrophils were found in the lung, which progressed to a diffuse exudative pneumonia by $7 \mathrm{~d}$ (36). Interestingly, the acute inflammatory response was partially resolved after prolonged exposure $(>10 \mathrm{~d})$ in these animals, with thickened alveolar walls persisting at this stage (36). This evidence of a resolution of the inflammatory response and the potential development of decreased responsiveness to ureaplasmas is similar to that seen in sheep exposed to LPS (19) and may explain the lack of increased inflammatory response seen in our lambs.

The effects of chronic ureaplasma exposure on the immune response to ventilation injury may become more evident with prolonged ventilation. It is not known how the signaling pathways involved in VILI are affected by the presence of ureaplasmas, and it is not known whether decreased immune responsiveness or hyperresponsiveness would occur. In an antenatal mouse model of ureaplasma colonization with signs of perinatal inflammation, there was proinflammatory cytokine activation (MCP-1, IL-1 $\beta$, and IL-6) and ureaplasma colonization cleared by postnatal day 3.5 (37). These mice had an increased inflammatory response to hyperoxia relative to uninfected mice (37). In our study, UP exposed lambs and controls had similar $\mathrm{PaO}_{2}$ and oxygenation, and proinflammatory cytokine mRNA levels were not different. The difference between our study and that of Normann et al. (37) may again be due to the development of tolerance phenomenon to ureaplasmas similar to that seen in sheep exposed to LPS. If tolerance occurred, we would expect less stimulation of proinflammatory mediators.

The lack of a difference between lambs exposed to ureaplasmas and uninfected lambs may be due to the experimental design. Lambs receiving high $V_{\mathrm{T}}$ ventilation (escalating $V_{\mathrm{T}}$ to $15 \mathrm{~mL} / \mathrm{kg}$ by $15 \mathrm{~min}$ ) may have enough additional inflammation and alveolar protein increases to mask the effects of previous exposure to ureaplasma. The lambs in noninjurious ventilation groups received surfactant before ventilation, 
which may have negated any difference in inflammatory response. Although we developed the protocol to provide noninjurious ventilation, based on recommendations to give surfactant before ventilation and to use of low $V_{\mathrm{T}} \mathrm{s}$, we caused significant damage with the initiation of ventilation. The initiation of ventilation in preterm sheep leads to airway epithelial injury and cytokine production from cells surrounding the smaller airways (27). As fluid is cleared from the airways, initial breaths may distend the airway and cause injury (2). Egr-1 protein activated as early as 15 min after ventilation in preterm sheep (38) and has been localized to the cells surrounding the airways when ventilation is initiated in fetal sheep (27). Ureaplasma colonization tends to decrease Egr-1 protein signaling when animals are ventilated, but even small increases in this transcription factor can lead to activation of the inflammatory cascade. The use of mechanical ventilation in the preterm lamb, even with low $V_{\mathrm{T}} \mathrm{s}$ and surfactant, leads to lung injury and inflammation.

Intraamniotic UP does not cause early preterm birth in sheep, consistent with our experience with other proinflammatory stimuli in sheep including endotoxin (39) and IL-1 (40) but contrasts with what occurs, or would be expected to occur, in other species, including humans. Sheep are relatively protected from inflammation-induced preterm birth due to subtle differences in the control of parturition and not because of differences in fundamental inflammatory processes. Differences in the virulence of serovars used across many studies may also contribute to differences observed in our model; however, UP serovar 3 is one of the most frequently observed serovars isolated from women who have delivered preterm (11).

\section{CONCLUSIONS}

Antenatal colonization with UP serovar 3, injected $55 \mathrm{~d}$ before delivery, did not change ventilation variables or affect the lung injury and inflammation from initiation of ventilation. The initiation of ventilation in preterm sheep caused lung injury that was not modulated by previous exposure to ureaplasmas.

Acknowledgments. We gratefully acknowledge the assistance of JRL Hall \& Co. for the supply of the sheep, particularly Ross Wales, Sara Ritchie, and Fiona Hall. We also thank Ms. Carryn McLean, Mr. David Cruise, and Ms. Eva Schwaiger for their assistance in delivering and caring for the lambs and performing postmortem tissue preparations and analyses, and Ms. Samantha Dando for performing the ureaplasma culturing of all tissue specimens.

\section{REFERENCES}

1. Schmolzer GM, Te Pas AB, Davis PG, Morley CJ 2008 Reducing lung injury during neonatal resuscitation of preterm infants. J Pediatr 153:741-745

2. Jobe AH, Hillman N, Polglase G, Kramer BW, Kallapur S, Pillow J 2008 Injury and inflammation from resuscitation of the preterm infant. Neonatology 94:190-196

3. Lahra MM, Jeffery HE 2004 A fetal response to chorioamnionitis is associated with early survival after preterm birth. Am J Obstet Gynecol 190:147-151

4. Romero R, Espinoza J, Gonçalves LF, Kusanovic JP, Friel LA, Nien JK 2006 Inflammation in preterm and term labour and delivery. Semin Fetal Neonatal Med. $11: 317-326$
5. Stenmark KR, Abman SH 2005 Lung vascular development: implications for the pathogenesis of bronchopulmonary dysplasia. Annu Rev Physiol 67:623-661

6. Speer CP 2006 Inflammation and bronchopulmonary dysplasia: a continuing story. Semin Fetal Neonatal Med 11:354-362

7. Schelonka RL, Katz B, Waites KB, Benjamin DK Jr 2005 Critical appraisal of the role of Ureaplasma in the development of bronchopulmonary dysplasia with metaanalytic techniques. Pediatr Infect Dis J 24:1033-1039

8. Castro-Alcaraz S, Greenberg EM, Bateman DA, Regan JA 2002 Patterns of colonization with Ureaplasma urealyticum during neonatal intensive care unit hospitalizations of very low birth weight infants and the development of chronic lung disease. Pediatrics 110:e45

9. Moss TJ, Nitsos I, Ikegami M, Jobe AH, Newnham JP 2005 Experimental intrauterine Ureaplasma infection in sheep. Am J Obstet Gynecol 192:1179-1186

10. Moss TJ, Nitsos I, Knox CL, Polglase GR, Kallapur SG, Ikegami M, Jobe AH, Newnham JP 2009 Ureaplasma colonization of amniotic fluid and efficacy of antenatal corticosteroids for preterm lung maturation in sheep. Am J Obstet Gynecol 200:96.e1-96.e6

11. Katz B, Patel P, Duffy L, Schelonka RL, Dimmitt RA, Waites KB 2005 Characterization of ureaplasmas isolated from preterm infants with and without bronchopulmonary dysplasia. J Clin Microbiol 43:4852-4854

12. Knox CL, Timms P 1998 Comparison of PCR, nested PCR, and random amplified polymorphic DNA PCR for detection and typing of Ureaplasma urealyticum in specimens from pregnant women. J Clin Microbiol 36:3032-3039

13. Knox CL, Allan JA, Allan JM, Edirisinghe WR, Stenzel D, Lawrence FA, Purdie DM, Timms P 2003 Ureaplasma parvum and Ureaplasma urealyticum are detected in semen after washing before assisted reproductive technology procedures. Fertil Steril 80:921-929

14. Kirchner L, Helmer H, Heinze G, Wald M, Brunbauer M, Weninger M, Zaknun D 2007 Amnionitis with Ureaplasma urealyticum or other microbes leads to increased morbidity and prolonged hospitalization in very low birth weight infants. Eur J Obstet Gynecol Reprod Biol 134:44-50

15. Perni SC, Vardhana S, Korneeva I, Tuttle SL, Paraskevas LR, Chasen ST, Kalish RB, Witkin SS 2004 Mycoplasma hominis and Ureaplasma urealyticum in midtrimester amniotic fluid: association with amniotic fluid cytokine levels and pregnancy outcome. Am J Obstet Gynecol 191:1382-1386

16. Moss TJ, Knox CL, Kallapur SG, Nitsos I, Theodoropoulos C, Newnham JP, Ikegami M, Jobe AH 2008 Experimental amniotic fluid infection in sheep: effects of Ureaplasma parvum serovars 3 and 6 on preterm or term fetal sheep. Am J Obstet Gynecol 198:122.e1-122.e8

17. Yoder BA, Coalson JJ, Winter VT, Siler-Khodr T, Duffy LB, Cassell GH 2003 Effects of antenatal colonization with ureaplasma urealyticum on pulmonary disease in the immature baboon. Pediatr Res 54:797-807

18. Polglase GR, Hillman NH, Ball MK, Kramer BW, Kallapur SG, Jobe AH, Pillow JJ 2009 Lung and systemic inflammation in preterm lambs on continuous positive airway pressure or conventional ventilation. Pediatr Res 65:67-71

19. Kallapur SG, Jobe AH, Ball MK, Nitsos I, Moss TJ, Hillman NH, Newnham JP, Kramer BW 2007 Pulmonary and systemic endotoxin tolerance in preterm fetal sheep exposed to chorioamnionitis. J Immunol 179:8491-8499

20. Hillman NH, Moss TJ, Kallapur SG, Bachurski C, Pillow JJ, Polglase GR, Nitsos I, Kramer BW, Jobe AH 2007 Brief, large tidal volume ventilation initiates lung injury and a systemic response in fetal sheep. Am J Respir Crit Care Med 176:575-581

21. Notter RH, Egan EA, Kwong MS, Holm BA, Shapiro DL 1985 Lung surfactant replacement in premature lambs with extracted lipids from bovine lung lavage: effects of dose, dispersion technique, and gestational age. Pediatr Res 19:569-577

22. Jobe AH, Kramer BW, Moss TJ, Newnham JP, Ikegami M 2002 Decreased indicators of lung injury with continuous positive expiratory pressure in preterm lambs. Pediatr Res 52:387-392

23. Lowry OH, Rosebrough NJ, Farr AL, Randall RJ 1951 Protein measurement with the Folin phenol reagent. J Biol Chem 193:265-275

24. Kallapur SG, Willet KE, Jobe AH, Ikegami M, Bachurski CJ 2001 Intra-amniotic endotoxin: chorioamnionitis precedes lung maturation in preterm lambs. Am J Physiol Lung Cell Mol Physiol 280:L527-L536

25. Hillman NH, Moss TJ, Nitsos I, Kramer BW, Bachurski CJ, Ikegami M, Jobe AH, Kallapur SG 2008 Toll-like receptors and agonist responses in the developing fetal sheep lung. Pediatr Res 63:388-393

26. Kramer BW, Moss TJ, Willet KE, Newnham JP, Sly PD, Kallapur SG, Ikegami M, Jobe AH 2001 Dose and time response after intraamniotic endotoxin in preterm lambs. Am J Respir Crit Care Med 164:982-988

27. Hillman NH, Kallapur SG, Pillow JJ, Moss TJ, Polglase GR, Nitsos I, Jobe AH 2001 Airway injury from initiating ventilation in preterm sheep. Pediatr Res 67:60-65

28. Kallapur SG, Nitsos I, Moss TJ, Polglase GR, Pillow JJ, Cheah FC, Kramer BW, Newnham JP, Ikegami M, Jobe AH 2009 IL-1 mediates pulmonary and systemic inflammatory responses to chorioamnionitis induced by LPS. Am J Respir Crit Care Med 179:955-961

29. Kramer BW, Ikegami M, Moss TJ, Nitsos I, Newnham JP, Jobe AH 2005 Endotoxininduced chorioamnionitis modulates innate immunity of monocytes in preterm sheep. Am J Respir Crit Care Med 171:73-77

30. Andrews WW, Goldenberg RL, Faye-Petersen O, Cliver S, Goepfert AR, Hauth JC 2006 The Alabama Preterm Birth study: polymorphonuclear and mononuclear cell placental infiltrations, other markers of inflammation, and outcomes in 23- to 32-week preterm newborn infants. Am J Obstet Gynecol 195:803-808

31. Van Marter LJ, Dammann O, Allred EN, Leviton A, Pagano M, Moore M, Martin C 2002 Chorioamnionitis, mechanical ventilation, and postnatal sepsis as modulators of chronic lung disease in preterm infants. J Pediatr 140:171-176

32. Witt A, Berger A, Gruber CJ, Petricevic L, Apfalter P, Worda C, Husslein P 2005 Increased intrauterine frequency of Ureaplasma urealyticum in women with preterm 
labor and preterm premature rupture of the membranes and subsequent cesarean delivery. Am J Obstet Gynecol 193:1663-1669

33. Kallapur SG, Nitsos I, Moss TJ, Kramer BW, Newnham J, Ikegami M, Jobe AH 2005 Chronic endotoxin exposure does not cause sustained structural abnormalities in the fetal sheep lungs. Am J Physiol Lung Cell Mol Physiol 288:L966-L974

34. Viscardi R, Manimtim W, He JR, Hasday JD, Sun CC, Joyce B, Pierce RA 2006 Disordered pulmonary myofibroblast distribution and elastin expression in preterm infants with Ureaplasma urealyticum pneumonitis. Pediatr Dev Pathol 9:143-151

35. Viscardi RM, Atamas SP, Luzina IG, Hasday JD, He JR, Sime PJ, Coalson JJ, Yoder BA 2006 Antenatal Ureaplasma urealyticum respiratory tract infection stimulates proinflammatory, profibrotic responses in the preterm baboon lung. Pediatr Res 60:141-146

36. Novy MJ, Duffy L, Axthelm MK, Sadowsky DW, Witkin SS, Gravett MG, Cassell GH, Waites KB 2009 Ureaplasma parvum or Mycoplasma hominis as sole patho- gens cause chorioamnionitis, preterm delivery, and fetal pneumonia in rhesus macaques. Reprod Sci 16:56-70

37. Normann E, Lacaze-Masmonteil T, Eaton F, Schwendimann L, Gressens P, Thebaud B 2009 A novel mouse model of Ureaplasma-induced perinatal inflammation: effects on lung and brain injury. Pediatr Res 65:430-436

38. Wallace MJ, Probyn ME, Zahra VA, Crossley K, Cole TJ, Davis PG, Morley CJ, Hooper SB 2009 Early biomarkers and potential mediators of ventilation-induced lung injury in very preterm lambs. Respir Res 10:19

39. Moss TJ, Nitsos I, Kramer BW, Ikegami M, Newnham JP, Jobe AH 2002 Intraamniotic endotoxin induces lung maturation by direct effects on the developing respiratory tract in preterm sheep. Am J Obstet Gynecol 187:1059-1065

40. Willet KE, Kramer BW, Kallapur SG, Ikegami M, Newnham JP, Moss TJ, Sly PD, Jobe AH 2002 Intra-amniotic injection of IL-1 induces inflammation and maturation in fetal sheep lung. Am J Physiol Lung Cell Mol Physiol 282:L411-L420 